\title{
Signals from the Tenth Justice: The Political Role of the Solicitor General in Supreme Court Decision Making
}

\author{
Michael A. Bailey Georgetown University \\ Brian Kamoie George Washington University \\ Forrest Maltzman George Washington University
}

\begin{abstract}
Conventional explanations of the solicitor general's influence on the Supreme Court emphasize his expertise or experience. We articulate and test a more political account based on insights from signaling theory. We argue justices will be more receptive to signals from the solicitor general (S.G.) when either the justice and S.G. are ideologically proximate or the S.G.'s signal is contrary to his ideological predisposition. We test our account over the period from 1953 to 2002 using a newly developed interinstitutional measure of ideology that places executive and judicial actors on the same spatial scale. Our results highlight the political nature of the S.G.'s influence, challenging the received wisdom about the S.G.'s impact on the Supreme Court.
\end{abstract}

$\mathrm{T}$ he American system of shared powers features rich and complex interactions among the three branches of government. Although many aspects of these interactions are contested by judicial and legal scholars, few disagree that the executive branch-via the solicitor general (S.G.), its chief litigator-influences the Court. The solicitor general's successful track record is well established (Caldeira and Wright 1988; Caplan 1987; McGuire 1998; Salokar 1992; Scigliano 1971; O’Connor 1983; Segal 1988). In fact, the relationship between the Court and S.G. is said to be so close that the S.G. is often referred to as the "Tenth Justice" (Caplan 1987).

According to prevailing views, the solicitor general is influential either because he acts as an agent of the Court or because he has exceptional expertise and experience before the Court. These two factors are apolitical and suggest that justices will be uniformly receptive to the arguments made by the S.G. The apolitical view contradicts evidence that executive and judicial actors are, in fact, quite politi$\mathrm{cal}$, and that politics and law are at the intersection of the solicitor general's responsibilities (Pacelle 2003). To the extent that justices and the S.G. are political actors, we would expect significant variation in the influence of the S.G. on the views of those on the bench.

We propose and test a political signaling theory of the solicitor general's influence on the Court. In our account, the solicitor general's position in a case provides information to justices about the potential ideological impact of a case. Justices, as strategic actors (Epstein and Knight 1998; Maltzman, Spriggs, and Wahlbeck 2000; Murphy 1964), are unlikely to respond uniformly to these signals. Instead, relying on insights from signaling theory, we argue that justices will find a solicitor general's information more credible when the solicitor general and the justice are ideologically congruent or when the signal from the S.G. is ideologically counter to his typical policy views. To test our account, we model the solicitor general's success before the Court between 1953 and 2002. Our results lead to a nuanced and conditional understanding of the relationship between the Court and the executive branch.

Michael A. Bailey is Associate Professor of Government at Georgetown University, Washington, DC 20057 (baileyma@georgetown.edu). Brian Kamoie is Assistant Professor of Health Policy in the School of Public Health and Health Services and a PhD candidate in Political Science at George Washington University, Washington, DC 20052 (kamoie@gwu.edu). Forrest Maltzman is Professor of Political Science at George Washington University, Washington, DC 20052 (forrest@gwu.edu).

The authors appreciate the advice and assistance of Will Adams, Sarah Binder, Saul Brenner, Bert Kritzer, Eric Lawrence, Rich Pacelle, Ryan Pevnick, James Spriggs, and Paul Wahlbeck. Bailey and Maltzman also acknowledge the support of the National Science Foundation (SES-0351469; SES-03151763). Bailey acknowledges support from the Hoover Institution, Stanford University.

American Journal of Political Science, Vol. 49, No. 1, January 2005, Pp. 72-85 


\section{The Solicitor General and the Supreme Court}

It is widely accepted that the solicitor general has significant influence on the Court. This influence occurs at every stage of the process. The Supreme Court is more likely to grant certiorari in cases where the S.G. recommends that the Court accept the case for review (Caldeira and Wright 1988; Provine 1980; Tannenhaus et al. 1963; Ulmer 1984). At the merits stage, scholars have shown that the Supreme Court disproportionately sides with the S.G.'s position when he argues a case as a party, and even when he simply files an amicus brief (Epstein et al. 1996; Johnson 2002; McGuire 1998; O’Connor 1983; Puro 1981; Salokar 1992; Segal 1988; Segal and Reedy 1988). And the Court disproportionately incorporates the S.G.'s amicus brief arguments into its opinions (Spriggs and Wahlbeck 1997).

Judicial scholars have suggested two alternative explanations for the S.G.'s success before the Court. Both arguments are rooted in the quality of the legal information the S.G. provides in his oral and written arguments.

\section{Agent of the Court}

Many view the S.G. as an agent of the bench. Rather than simply representing the interests of the president and the administration, the S.G. is said to recognize his unique institutional position before the Court. As such, he seeks to provide legal information that is consistent with the Court's interests and capabilities. Moreover, the received wisdom holds that the Court affords the S.G. a unique position amongst the justices, leading many scholars to refer to the S.G. as the "Tenth Justice" (Caldeira and Wright 1988; Caplan 1987; Scigliano 1971; Segal 1988; Ulmer and Willison 1985). Consistent with this portrait of the S.G. is Perry's claim that when the S.G. makes recommendations regarding the granting of certiorari, the S.G. is "working almost as a surrogate for the Court, rather than as an unrestrained advocate for the government" (1991, 130).

Such a view of the S.G. is implicitly rooted in the legal model of judicial decision making. Because the S.G. so reliably provides the bench with information about the state of the law, the S.G. is easily able to secure the support of the justices. As summarized by Salokar (1992, 2), the success of the S.G. is "rooted in [the office's] independence from executive politics,... loyalty to the Court, and a personal dedication to the development of law."

\section{Repeat Player}

Galanter (1974), Segal (1988), Caldeira and Wright (1988), Spriggs and Wahlbeck (1997), and most notably McGuire (1998) suggest an alternative explanation for the success of the S.G. before the Court. Such studies focus on the status of the S.G. as a "repeat player." Such players benefit from the reputations they establish in the legal profession and in their performances before the Court and from their extensive experience in crafting arguments likely to sway the justices. Perry discovered the importance of being a repeat player when a former clerk told him that the S.G. was successful at the certiorari stage because "the solicitor general also knows all the catchwords, and they just know how to write them in a brief" $(1991,132)$. McGuire provides systematic evidence that for the 1977 through the 1982 terms the success of the solicitor general during oral argument stems from his relative legal skills (and the skills of the lawyers of his office). He concludes that, insofar as decisions on the merits are concerned, "the federal government is not, as some have suggested, the 'tenth justice"” $(1998,506)$.

Although the repeat player explanation for the success of the S.G. is different than the agent of the Court explanation, neither explanation suggests that political factors account for the success of the S.G. nor accounts for the individual variation in justices' responses to the S.G. As a result, evidence for both models has been derived by examining how often the majority of the Court rules consistent with the S.G.'s position.

\section{The Solicitor General as an Ideological Signal}

Recent theoretical approaches to understanding the Court-including the attitudinal and strategic models of Court decision making - should encourage us to look anew at the relationship between the S.G. and the Court. If justices are motivated primarily by their policy preferences (Segal and Spaeth 1993, 2002), we would not expect justices to accept the policy positions advocated by the S.G. without regard to the justices' and S.G.'s political views. Contrary to both the agent of the court and the repeat player accounts, this view should recognize that the receptivity of the Court to the S.G.'s arguments should depend on the ideological relationship between the S.G. and each justice. Hence, it should lead us to expect different solictors general to have different success rates and for there to be variation in the receptivity of different justices to different S.G.s. 
To be sure, the insights of the attitudinal model have not been ignored by scholars interested in the S.G. and the Court. As Segal argued 17 years ago, policy-motivated justices "should condition their support for the solicitor general on the ideological direction of the brief" (1988, 142). Although Segal only presents "preliminary findings" $(1988,142)$, he shows that liberal justices are more likely to support liberal amicus briefs filed by the S.G. and conservative justices are more likely to support conservative briefs filed by the S.G. Likewise, Segal and Spaeth (1993, 313) attribute the willingness of individual justices to vote with the S.G. to consistency between the S.G.'s position and the justice's preferences.

Such evidence suggests that the influence of the S.G. may not be uniform across justices. Still, as Segal and Reedy (1988) argue, "agreement is not effect. The fact that the Court agrees with the solicitor's position does not tell us that Court was influenced by his stand" (553). To determine influence, we need to control for judicial ideology in determining influence. Moreover, we need a theory that predicts the conditions under which the S.G. should be more or less influential. For these reasons, we agree with Segal's (1988) conclusion that "We are most in need of a decision-making model of judicial behavior that can incorporate the preferences of leading actors in the Court's political environment" (1988, 142-43).

We believe that a signaling model can account for the S.G.'s influence with the court. Signaling theory explores the conditions under which such information can be credibly transmitted from one actor to another (Crawford and Sobel 1982; Li and Wing 2004). Signaling models are based upon two premises. First, the models assume that an information asymmetry exists among different actors. As a result, a "sender" (who in our case corresponds to the S.G.) who possesses some privately observed information transmits a "message" to a "receiver" (who in our case is a Supreme Court justice).

Second, the models are based upon the premise that the receiver recognizes that the signal sent by the sender may be incomplete or inaccurate. This may occur because the sender has preferences that are distinct from those of the recipient and thus intentionally distorts the message he or she is sending. As a result, receivers take into account the sender's preferences when evaluating the quality of a signal sent. For this reason, receivers develop various strategies to glean information about the sender. In the case of the Court, justices interact repeatedly with the S.G. and thus are likely to possess a great deal of information about the S.G.'s preferences.

We believe that Supreme Court justices are likely, at least in part, to view amicus curiae briefs filed by the solicitor general as signals that reflect the S.G.'s reading of the law and potentially the administration's policy biases. ${ }^{1}$ These signals are useful for helping the justices decide how the law should be framed. ${ }^{2}$ Thomas W. Merrill, deputy S.G. from 1987 to 1990, recognized as much when he argued that George W. Bush's decision to instruct the S.G. to participate as amicus in the University of Michigan affirmative action cases (Grutter v. Bollinger, 02-241; Gratz v. Bollinger, 02-516) was important because justices "look to the solicitor general for guidance... for signals about the political atmosphere, "for what's do-able" (Greenhouse 2003). Merrill also recognized that a justice's interpretation of the signal would depend upon his or her understanding of the administration's policy biases: "If a conservative administration doesn't take a strong position in a particular case, that's a signal" (Greenhouse 2003).

The heuristic example depicted in Figure 1 helps us apply the theory to relations between the solicitor general and the Court. Policy space is one-dimensional, and we assume preferences are single-peaked. There is a single justice who is ideologically located at the point marked "Justice," and the solicitor general is more conservative than the justice, with his ideal point marked "S.G." For simplicity, we refer to the justice as female and the S.G. as male.

On any given case there will be a policy outcome associated with voting liberally and a policy outcome associated with voting conservatively. The midpoint between these liberal and conservative policy outcomes for a particular case is what is typically referred to as the "cutpoint."

\footnotetext{
${ }^{1}$ We focus on amicus filings because they are most often filed at the discretion of the S.G. and thus are most likely to contain political signals (Meinhold and Shull 1998). Nevertheless, it is important to note that on occasion briefs filed by the S.G. when the United States is named as a respondent may also provide a political signal. Our analysis is limited to amici because the decision to appeal a case where the United States is a party and wins at the lower level is not made by the S.G. Even when the U.S. is a direct party to the case and loses at the lower level, the fact that a case ends up before the Supreme Court is likely to reflect more than ideological preferences of the administration. This occurs for two reasons. First, many of the cases where the U.S. is a party end in the judicial system principally because a decision made by the opposing party, rather than the federal government. Second, the decision to appeal a lower court loss might be made on the basis of legal strategy, a desire to avoid bringing a case to the attention of the Supreme Court and thus establishing a precedent that is not in the interest of the U.S., the financial cost of the loss to the U.S., the fact that there are other U.S. cases that are more important, etc. These factors are likely to play a very important role (if not determinative) role. Knowing this, justices are less likely to view the S.G.'s position as a political signal when the U.S. is a party. Because the S.G.'s decision to participate as a party is constrained, Pacelle notes, amici briefs filed by the S.G. "provide the best opportunity to further executive designs" (2003, $10)$.

${ }^{2}$ For a discussion of the importance of interinstitutional signaling see Eskridge and Frickey (1994).
} 


\section{FIGURE 1 Hypothetical Court and Signals About Cutpoint}

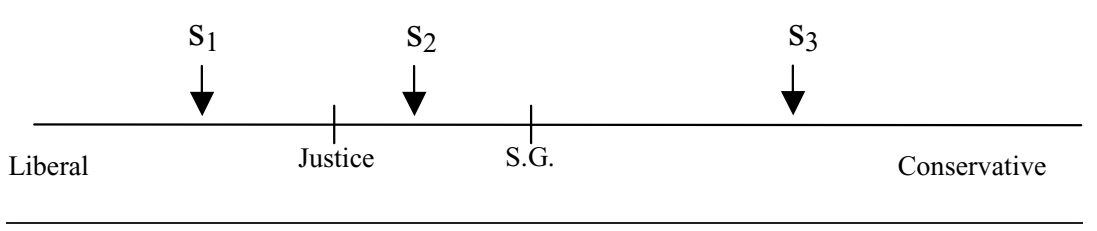

The S.G. and justice do not know the exact location of these policy outcomes, so they have to make informed estimates about where they lie. If, based on her best estimate of the policy locations, the justice believes the conservative outcome is closer to her ideal point, she will favor the conservative outcome; if the justice believes the liberal outcome is closer, she will favor the liberal outcome. Hence, the decision calculus of the justice reduces to calculating whether her ideal point is to the left or the right of the cutpoint. The amicus brief filed by the S.G. informs the justices of the S.G.'s understanding of where the cut point resides and recommends whether the justice should vote in a liberal or conservative direction. ${ }^{3}$

The solicitor general develops some idea of where the true cutpoint is located; this is his private information. For simplicity, we assume that the S.G. learns that the cutpoint is one of three possible locations: $s_{1}, s_{2}$, and $s_{3}$. If the S.G. were somehow forced to fully and truthfully reveal his private information, this information would prove very helpful to the justice. A suggestion by the S.G. that the cutpoint is at $s_{1}$ would lead the moderate justice to opt for a conservative outcome. If the S.G. revealed that he observed a cutpoint at $s_{2}$ or $s_{3}$, the justice would vote liberally. ${ }^{4}$

\footnotetext{
${ }^{3}$ The S.G.'s identification of the cutpoint stems from his discussion as to where the law currently stands and what a particular decision would mean for the development of the law. For example, if the S.G. informed the justices that ruling in favor of Barbara Gutter in Gutter v. Bollinger would assist the administration in its goal of eliminating of all affirmative action programs, he would be placing the cutpoint on the right hand side of ideological spectrum. On the other hand, if the S.G. pointed out that ruling in favor of Barbara Gutter would only curtail programs that pertained to public institutions the S.G. would be helping the justices understand that the cutpoint was not on the extreme right.

${ }^{4}$ To make the argument more concrete, consider Figure 1 in terms of the way in which the Court will deal with reductions in detainee rights associated with antiterrorism efforts (as regards to the cases emanating from Jose Padilla's and Yaser Hamdi's detention as enemy combatants). Suppose that the dimension orders political actors according to their willingness to reduce rights in the face of security threats. The signals are about level of threat associated with providing all detainees the full legal rights accorded in ordinary times. A low signal $\left(s_{1}\right)$ would be indicative of a very high level of threat, such that both S.G. and the justice would prefer restriction on rights; a high signal $\left(s_{3}\right)$ would be indicative of a low
}

The problem, of course, is that the S.G. may have incentives to not fully or truthfully reveal what he knows. A strategic S.G. who knows that the cutpoint is $s_{2}$ might claim the cutpoint was $s_{1}$ in an effort to deceive the justice into voting conservatively in accordance with the S.G.'s preferences even though a fully informed justice would prefer the liberal outcome. Hence, whenever the S.G. signals to the justice that a conservative outcome is necessary a wise justice would be uncertain whether the S.G. was accurately passing on information.

Signaling theory shows that this problem inhibits transmission of information, but does not rule it out. There are, generally speaking, two situations that facilitate information transmission. In the first, the sender and receiver are ideologically proximate to each other (Crawford and Sobel 1982). In this case, the receiver has good reason to trust the signal sent by the sender. For example, if the ideal point of the S.G. in Figure 1 were between $s_{1}$ and $s_{2}$ (as is the justice), then for none of the three possible signals would the S.G. and justice have divergent preferences. Under this scenario, the S.G. has no incentive to mislead the justice. This is why it is a universal theme in signaling models that information transmission is more precise the closer the preferences of the sender and receiver.

In the second, the S.G. sends a signal that is counter to his ideological predisposition relative to the receiver. As Calvert has argued, "a biased advisor recommending the alternative he was supposed to have been biased against is likely thereby to prevent the decision maker from making a relatively large error" $(1985,552)$. For example, in Figure 1, if the relatively conservative S.G. suggests that a liberal outcome is desirable since the cutpoint is $s_{3}$, the justice would be wise to accept the position embraced by the S.G. On the other hand, if the relatively conservative S.G. suggests that the liberal justice should prefer a conservative outcome since the cutpoint is $s_{1}$, the justice should be skeptical of the S.G.'s signal. Indeed, the true cutpoint might be a point $\left(s_{2}\right)$ where the S.G. prefers a conservative outcome and the justice prefers a liberal outcome.

level of threat such that both actors would prefer no restriction on rights. A middle signal $\left(s_{2}\right)$ would indicate a modest threat level that would induce the justice to want no restrictions of rights, but would induce the S.G. to favor restrictions of rights. 
More generally, the value of the signal sent to a justice depends upon the position taken by the S.G. and the relative preferences of both the justice and the S.G. Whenever a S.G. who is more conservative than the justice takes a liberal position, the justice can infer that if the information were compelling enough to make the conservative take a liberal position, the information should in all likelihood be more compelling to someone who is more liberal in the first place. The logic works equally well (in reverse) when a more liberal S.G. takes a conservative position.

We can translate these themes from signaling theory into specific hypotheses about how Supreme Court justices will respond to messages from the solicitor general. The first important conjecture is that the credibility of the message increases with the ideological compatibility of the solicitor general and each of the Supreme Court justices.

\section{Ideological Compatibility Hypothesis: The closer the policy views of the justice to the solicitor general, the more likely the justice will support the position ad- vocated by the solicitor general; the more distant the justice is ideologically from the solicitor general, the less likely that justice will be to support the position advocated by the S.G.}

We expect to find systematic variation in justices' receptivity to the signals sent by the solicitor general.

The credibility of a signal also increases when the sender of the message takes a position against his or her policy predisposition and in favor of the justice's predisposition. For the reasons outlined above, moderate and liberal members of the Court may be duly skeptical of claims by a conservative S.G. about the legal merits of the conservative position. But these same members may be much more open to claims by a liberal S.G. that the conservative position is legally meritorious. Given that the liberal S.G. is predisposed toward supporting liberal outcomes, these justices could reasonably infer that the S.G.'s decision to support a conservative position is driven by legal concerns. This is particularly the case if the S.G. and the justice have distinct policy preferences. Even after controlling for each justice's policy predispositions, a justice who is extremely conservative is likely to take the information conveyed by a liberal S.G. embracing a conservative position more seriously than a moderate justice. This leads to our second major signaling hypothesis:

Outlier Signal Hypothesis: A justice will be more likely to support the solicitor general when the S.G.

\begin{abstract}
is more liberal than the justice and takes a conservative position or when the S.G. is more conservative than the justice and takes a liberal position. This is particularly true when the policy views of the justice and the solicitor S.G. are distant.
\end{abstract}

\section{Data and Methods}

The agent of the court and the repeat player explanations have been tested by looking at the relationship between the positions argued by the S.G. and the final outcome of interest (i.e., the decision to grant certiorari, the Court's ruling on the merits, and the incorporation of the S.G.'s views into the majority opinion). As such, empirical evidence on the S.G.'s performance is typically analyzed at the aggregate level. Because those approaches seek to explain the overall success record of the S.G. aggregate correlations between the actions of the S.G. and the responses of the Court are appropriate.

Such aggregate level tests, however, cannot detect the political story; it is in the variation across the justices in their receptivity to the S.G.'s arguments that politics enters the Court. Nor can we tell from such tests whether variation in the views of the solicitor general over time affect the likelihood that different justices will follow the cues of the solicitor general. Tests of the ideological signaling perspective require individual-level data about the views of the solicitor general (and the president he or she represents) and the resulting vote choices of each of the justices.

\section{Dependent Variable and Methods}

To test our expectations, we estimate whether a justice voted to endorse the position embraced in an amicus brief filed by the solicitor general on the merits for every civil liberties case with a signed opinion for the 1953 term through the 2002 term. ${ }^{5}$ We measure the positions taken

\footnotetext{
${ }^{5}$ We limit cases to civil liberties cases in order to account for the possibility that changes in the court's agenda make over time comparisons difficult (see Groseclose, Levitt, and Snyder 1999; Shipan and Lowry 2001 for a discussion of problems associated with the development of intertemporal measures). Specifically, in terms of Spaeth variables, we look at cases with ANALU $=0$ and VALUE $<6$. Admittedly, the price of focusing on civil liberties cases is that our results might not be generalizable to other areas of the law.

Because we need to know the direction of the court's ruling to calculate one of our independent variables (ideological propensity), we dropped the few cases where Gibson (1997) and Spaeth (1999) disagreed on the direction of the final disposition. We also dropped from our analysis cases where a new administration had come into office and the S.G. was either acting or a holdover from the
} 
by the S.G. in the following manner. For each case, we determine whether S.G. filed an amicus brief; whether such a brief supported the respondent or petitioner; and whether the brief advocated a conservative or liberal outcome. ${ }^{6}$ We then relied upon Spaeth $(1999,2002)$ to determine whether each justice's vote matched the position advocated by the S.G. If a justice's vote concurred with the position advocated by the S.G., the observation is coded $+1,0$ otherwise.

Because our dependent variable is dichotomous, we use a probit model. Because each of the justices in our data appears repeatedly over time, it is likely that the residual for a particular justice voting with the S.G. on a particular case is correlated with the same residual for that justice in another case. We control for correlated errors by using robust variance estimator. ${ }^{7}$

\section{Political Signaling Variables}

Critical to testing a theory of ideological signaling are estimates of the ideological views of the players. In the context of a signaling game between two branches of government, estimation of players' preferences is not a simple task. The difficulty lies in ensuring that the preference measures are compatible across the two branches. For us, institutionally compatible measures are essential because to test our theoretical expectations we need to know the ideological distance between the S.G. and each justice, and we need to be able to identify whether the S.G. generally prefers policies to the left or right of each justice. Most studies simply assume that measures of ideology based on legislative roll-call votes are directly comparable to measures of ideology based on justices' votes. From a measurement perspective, this is difficult to justify. Given differences in the agenda and context of the legislative and judicial branch's voting records, we cannot know how preference estimates from legislative votes compare to preference estimates from the Court. The potential for error is serious

previous administration. As we explain, we assume that the S.G. and President's preferences are closely aligned. This assumption seems less likely to hold for acting or holdover S.G.s. We did, however, run the analysis that we report including these cases. The results are similar and there is no substantive difference. The results are available from the first author.

${ }^{6}$ To identify whether the solicitor general filed an amicus brief, we relied upon Gibson (1997) for the period 1953 through 1987 and upon Lexis-Nexis Academic Universe and the solicitor general's web site for the period 1988 through 2001. Only amicus filings filed at the merit stage are included.

${ }^{7}$ We use Stata's robust command, clustering on the thirty-one justices in our study. and skews in measurement could skew our hypotheses tests.

To create interinstitutionally comparable estimates of ideology, we follow Bailey (2003). In this approach, "bridge" observations provide fixed references against which the preferences of presidents, senators, and justices can be estimated and compared. For the 40-year period we study, there are 1,130 bridge observations based on public statements by presidents and members of the Senate, amicus filings by members of the Senate, and Senate roll-call votes that explicitly take a position on Supreme Court cases. Although our interest in the bench's reactions to amicus filings by the S.G. mean that we only need to have the executive and judicial branches on the same scale, we include the statements, amicus filings, and votes of senators to increase the number of bridge observations and our confidence in the interinstitutional linkages. The estimation method is a Bayesian Markov Chain Monte Carlo (MCMC) procedure that allows justices' ideologies to vary over the course of their careers. Additional details on the methodology appear in the appendix.

These interinstitutionally comparable ideology estimates accord with intuition and are strongly correlated with judicial voting behavior. For the presidents, the rank ordering from the left to the right is (where low values represent liberal policy views, and high values represent conservative policy views): Kennedy, Johnson, Clinton, Carter, Eisenhower, Nixon, Ford, George H.W. Bush, George W. Bush, and Reagan. For the justices, Douglas, Goldberg, Marshall, Fortas, and Brennan anchor the left; Thomas, Rehnquist, Scalia, Burger, and Reed, the right. The correlation between the average yearly ideological score that we calculate for each justice who served between 1953 and 2002 and the percentage of the time they vote in liberal direction on civil liberties issues (Epstein et al. 2003, Table 6-2) is -0.98 .

We use the ideology measure based upon bridge observations to construct variables needed to test the ideological signaling hypotheses. The measures are as follows:

Distance from S.G. is the absolute value of the distance between the ideology of the justice and the S.G. We assume that the solicitor general is a direct agent of the president, and thus represents the policy views of the president in amicus briefs. ${ }^{8}$ The

\footnotetext{
${ }^{8}$ Several institutional factors and empirical evidence support the contention that the solicitor general's actions reflect the goals and preferences of the president. First, there is the explicit chain of command: "It is the President who, by statute, nominates the Solicitor General and at whose pleasure he serves. Should he care to, the President has the coercive language to direct the activities of even a reticent Solicitor General" (Cooper 1990, 7). Former S.G. Starr
} 
further the S.G. is from a justice, the less likely the signal will carry weight, implying that we expect the coefficient on this variable to be negative.

Outlier Signal is the ideological distance between the S.G. and the justice when the S.G. is more liberal than the justice and advocates a conservative position or when the S.G. is more conservative than the justice and advocates a liberal position. The variable is zero in all other cases. ${ }^{9}$ Consistent with our theoretical expectations, Outlier Signal takes into account the S.G.'s ideological predisposition; the position the S.G. takes on a particular case; and the relationship that exists between each justice and the S.G. This variable takes on a high value when a S.G. who is significantly more conservative than a justice takes a liberal position, or a S.G. who is significantly more liberal takes a conservative position. Because the logic of signaling theory implies that signals sent under these conditions should be particularly clear and thus carry more weight, we expect the coefficient on this variable to be positive.

\section{Control Variables}

To minimize the possibility that omitted variable bias affects our results, we control for a number of factors that may affect court voting. First, we recognize that agree-

explains, "As Solicitor General... I was an 'inferior' or 'subordinate' officer in the executive branch. If I could not in conscience abide by the president's judgment, then I should resign" $(2002,143)$. Second, statistical evidence indicates that presidential preferences are correlated with the S.G.'s decision to participate as an amicus (Meinhold and Shull 1998). Consistent with this, we conducted an extensive search for presidential statements on Supreme Court cases and identified 27 cases in which the president made a statement on a case where the S.G. participated as an amicus. In every one of these instances, the president publicly embraced the position advocated by his S.G. Third, there are many examples of presidents explicitly guiding S.G. activities. For example, Fraley $(1996,22)$ claims that President Clinton ordered his S.G.s to change positions on cases (Fraley 1996, 22). Likewise, Solicitors General Lee (1986, $599)$, Starr $(2002,143)$, and Days each claimed that they on occasion were directed by the President to make a specific filing (1994, 492-93).

${ }^{9}$ The value for this variable is zero in $64.2 \%$ of the observations. Because we never identified a justice with preferences that are identical to those of the S.G., every zero stems the S.G.'s failure to embrace a position contrary to how the justice perceived the S.G.'s preferences. Although the ideological distance variable is a component of our outlier variable, the correlation between these two variables is at a level where we are not concerned with multicolinearity (0.35). ment with the S.G. does not, in and of itself, indicate that the S.G. had any influence. If a justice votes with the S.G. because the S.G. favored a liberal outcome and the justice is liberal, what appears to be S.G. influence might be little more than ideological congruence. We created a variable that captures the ideological propensity of each justice to support the S.G.'s position. To calculate this score, we multiplied each justice's bridge based ideology score by 1 when the S.G. advocates a conservative outcome. ${ }^{10}$ When the S.G. advocates a liberal outcome, we calculate each justice's ideological propensity by multiplying each justice's bridge based ideology score by -1 . Since liberal justices have negative ideology scores, a high score suggests an ideological predisposition to support the S.G.'s position.

Ideological congruence might not be the only factor that leads some justices to be more predisposed to supporting the S.G. The need for the sort of expertise that the S.G. can provide is also likely to arise amongst justices who are new to the bench. Several studies have found that justices who are new to the bench may not have the knowledge of their more informed colleagues and thus need greater assistance in reaching decisions (Brenner and Hagle 1996; Hagle 1993). The solicitor general may be in a unique position to provide such assistance. To control for this possibility, we include in our model a dummy denoting any justice who was serving during one of his or her first three terms when the Court issued its opinion (freshman). Our expectation is that the S.G.'s influence will be greater for these justices.

It is also possible that the impact of the solicitor general's ideological signal may vary over the cases on the Court's docket. According to President Reagan's Solicitor General Rex Lee, the solicitor general frequently participated in cases because they were "at the 'core of the current administration's broader agenda"' (Lee 1986, 599). If a case is politically salient, the information needs of an individual justice may be diminished. As a result, justices may be less likely to be influenced by the solicitor general. Such a claim is comparable to Maltzman, Spriggs, and Wahlbeck's (2000) claim that on politically salient cases, justices' personal preferences are more pronounced, and thus they are less likely to be influenced by their colleagues. To identify those cases that are politically salient, we created a dummy variable to denote whether a case

\footnotetext{
${ }^{10}$ To determine whether the position advocated by the S.G. was liberal or conservative, we identified whether each brief filed by the S.G. supported the petitioner or the respondent. We then utilized Spaeth $(1999 ; 2002)$ to ascertain whether the respondent or petitioner won and whether this outcome was in a liberal or conservative outcome.
} 
was discussed on the front page of the New York Times (Political Salience) ${ }^{11}$

Cook (1993) and Brenner (1998) argue that case importance operates on both a political and legal dimension. Cases that are politically salient might have a limited impact on the development of the law. In contrast, legally salient cases have a broad legal impact. Justices may have less of a need for external information on these cases that are central to the Court's agenda. Thus, we would expect the S.G. to be less influential in these cases. Such a hypothesis is consistent with Maltzman, Spriggs, and Wahlbeck's (2000) claim that on legally (and politically) important cases, justices are less susceptible to being influenced by their colleagues. To determine whether a case was legally salient, we follow Maltzman, Wahlbeck, and Spriggs (2000) and create a dummy variable to identify cases in which the Court (according to Spaeth 1999, 2002) either struck a law down as unconstitutional, or overturned or altered precedent (Legal Salience).

Because the views of justices are likely to be most fluid on cases that are complex, we suspect that justices are most susceptible to the information provided by outside parties on complex cases. To control for this possibility, we include in our model a variable that taps the complexity of each case (Complexity). To do this, we combine the three indicators developed by Maltzman, Spriggs, and Wahlbeck (2000, 46), each derived from Spaeth (1999, 2002): the number of issues raised by the case, the number of legal provisions relevant to a case, and the number of opinions released in a case. We factor analyze the three indicators to produce factor scores for each case. As our measure of case complexity, we use the factor scores for the only factor that has an eigenvalue greater than one. If the S.G.'s views are more valuable for complex cases, we expect a positive coefficient.

The views of the S.G. are likely to be persuasive in those cases in which the Court invites the S.G. to participate (Invitation). Although the vast majority of the amicus briefs filed by the S.G. are filed at the discretion of the S.G., the Court regularly invites the S.G. to submit such a brief. Such an invitation is, for all practical purposes, an order to the S.G.'s office. In such cases, "the solicitor general is expected to provide nonpartisan advice to help the justices with their decision" (Pacelle 2002, 123). In these cases, the Court is unlikely to view the S.G.'s activism as a reflection of the administration's political agenda. Instead, the S.G.'s involvement reflects the fact that there is a federal interest

\footnotetext{
${ }^{11}$ For the 1951-1996 period, this data was provided by Epstein and Segal (2000). For the period between 1996 and 2001, we collected this data by search Lexis-Nexis for all front-page stories that contained the word "Supreme Court" and followed Epstein and Segal's coding instructions $(2000,73)$.
}

in this case. As a result, justices may be more likely to take the views of the S.G. seriously. To ascertain whether the value of the signal sent by the solicitor general is different when he lacks discretion to file an amicus brief, we created a dummy variable to demark cases where the Court invites the S.G. to participate. ${ }^{12}$

Finally, there are a priori empirical reasons to expect different solicitors general to have different degrees of success with their briefs. This may occur because each S.G. has a different level of appellate experience (McGuire 1998), for example. Therefore, we estimate a fixed-effects model, controlling for each confirmed S.G. ${ }^{13}$

\section{Results}

Table 1 summarizes our dependent variable and replicates Segal's (1988, Table 8) analysis for the cases that are included in our data base. Overall, justices embraced the position advocated by the S.G. $68 \%$ of the time. The fact that justices vote with the S.G. more than $50 \%$ of the time (the typical litigant's success rate) suggests that the validity of the conventional view that S.G.s have a substantial across-the-board effect. In recent decades, this most likely reflects the fact the S.G.'s status as a more experienced litigant (McGuire 1998). Such an explanation, however, cannot account for the variation across justices.

Table 1 also reports the proportion of the time that each justice voted with the S.G. when he embraced liberal and conservative outcomes and the significance of this difference. For example, Justice Brennan voted with the S.G. $25 \%$ of the cases when the S.G. embraced a conservative position and in $95 \%$ of the cases in which the S.G. embraced a liberal position. This difference is highly significant. The table shows that the liberal S.G. and conservative S.G. support scores are significantly different for 15 of the 17 justices (Stewart and White are the exceptions) who are in our data set and who participated in at least 10 cases where the S.G. advocated liberal outcome and 10 cases where he supported a conservative outcome. Although these facts do not test our signaling hypothesis, they are consistent with Segal's (1988) and Segal and Spaeth's (1993) observation that S.G. influence is attributable in large part to the alignment of preferences

\footnotetext{
${ }^{12}$ Alternatively, one could exclude from the analysis cases where the S.G. received an "invitation" to participate. The substantive results we report are the same when such an exclusion is made.

${ }^{13}$ We dropped cases involving S.G.s who were a holdover from a previous administration of another party (e.g., Kenneth Starr served as S.G. under Bill Clinton for several months).
} 
TABLE 1 Support for the Solicitor General Amicus Positions (1953-2002 Terms)

\begin{tabular}{|c|c|c|c|c|c|c|}
\hline \multirow[b]{2}{*}{ Justice } & \multicolumn{4}{|c|}{ Percent Support for S.G. } & \multicolumn{2}{|c|}{ Number of S.G. Amicus Briefs Filed } \\
\hline & Overall & S.G. Liberal & S.G. Conservative & Chi-Sq. ${ }^{*}$ & S.G. Conservative & S.G. Liberal \\
\hline Black & 0.74 & 0.78 & 0.43 & - & 7 & 54 \\
\hline Reed & 1.00 & 1.00 & 1.00 & - & 1 & 2 \\
\hline Frankfurter & 0.73 & 0.80 & 0.00 & - & 1 & 10 \\
\hline Douglas & 0.80 & 0.97 & 0.13 & $51.31^{*}$ & 15 & 59 \\
\hline Jackson & 1.00 & 1.00 & - & - & & 2 \\
\hline Burton & 1.00 & 1.00 & 1.00 & - & 1 & 4 \\
\hline Clark & 0.79 & 0.82 & 0.50 & - & 4 & 44 \\
\hline Minton & 1.00 & 1.00 & 1.00 & - & 1 & 2 \\
\hline Warren & 0.92 & 0.96 & 0.50 & - & 6 & 53 \\
\hline Harlan & 0.47 & 0.49 & 0.25 & - & 4 & 51 \\
\hline Brennan & 0.55 & 0.95 & 0.25 & $128.71^{*}$ & 157 & 115 \\
\hline Whittaker & 0.75 & 0.75 & - & - & & 8 \\
\hline Stewart & 0.67 & 0.65 & 0.71 & 0.29 & 34 & 84 \\
\hline B. White & 0.79 & 0.74 & 0.82 & 2.78 & 192 & 117 \\
\hline Goldberg & 1.00 & 1.00 & - & - & & 25 \\
\hline Fortas & 0.73 & 0.82 & 0.40 & - & 5 & 17 \\
\hline Marshall & 0.42 & 0.96 & 0.16 & $138.23^{*}$ & 163 & 77 \\
\hline Burger & 0.79 & 0.59 & 0.92 & $23.99 *$ & 96 & 58 \\
\hline Blackmun & 0.61 & 0.85 & 0.51 & $28.94^{*}$ & 192 & 85 \\
\hline Powell & 0.73 & 0.58 & 0.82 & $11.82^{*}$ & 107 & 59 \\
\hline Rehnquist & 0.77 & 0.42 & 0.95 & $136.22^{*}$ & 246 & 130 \\
\hline Stevens & 0.48 & 0.76 & 0.34 & $58.54^{*}$ & 236 & 123 \\
\hline O’Connor & 0.77 & 0.65 & 0.82 & $9.80^{*}$ & 217 & 95 \\
\hline Scalia & 0.71 & 0.35 & 0.88 & $67.21^{*}$ & 151 & 72 \\
\hline A. Kennedy & 0.73 & 0.48 & 0.86 & $32.01^{*}$ & 127 & 67 \\
\hline Souter & 0.69 & 0.82 & 0.60 & $8.40^{*}$ & 92 & 65 \\
\hline Thomas & 0.64 & 0.28 & 0.90 & $56.30^{*}$ & 80 & 60 \\
\hline Ginsburg & 0.66 & 0.80 & 0.52 & $10.55^{*}$ & 60 & 56 \\
\hline Breyer & 0.75 & 0.87 & 0.65 & $6.21^{*}$ & 54 & 45 \\
\hline
\end{tabular}

* Significance of difference between support for S.G. when he urges a liberal and a conservative outcome. Critical value for $\alpha<0.05$ is 3.84. We did not calculate $\chi^{2}$ for any justice who did not participate in at least 10 cases where the S.G. participated as a liberal amici and 10 cases where the S.G. participated as a conservative amici.

between the S.G. and justices and illustrate the need to control for each justice's ideological predisposition.

In Table 2, we test our signaling model with a multivariate model of individual justices' support for the side advocated by the S.G. We estimate two specifications, one with only the basic ideological control and the other with the full complement of control variables. Since the results across the two models are consistent, we limit our discussion to the second, fully specified model. To interpret the model's coefficients, we assess in Table 3 the impact of each significant, independent variable (except for ideological propensity) from its minimum to maximum values, holding other significant variables (Distance from S.G.; Legal Salience; Political Salience) at their mean and the significant dichotomous variable (Freshmen) at its modal category. We hold the justice's ideology (Ideological Propensity) in the middle of the ideological scale. Hence, the probability of voting with the S.G. in our simulation is independent of the justice's ideological proclivities. For all the simulations except the one designed to help us understand the Outlier Signal variable, we also hold the Outlier at its modal category (0), simulating an S.G. who embraces a position consistent with their ideological orientation.

As shown in Table 2, our two main variables testing the ideological signaling role of the S.G. are statistically 


\section{TABLe 2 Probability of a Justice Voting in a Manner Consistent with S.G. Amicus Brief}

\begin{tabular}{|c|c|c|}
\hline \multicolumn{3}{|l|}{$\begin{array}{l}\text { Variable (expected sign) } \\
\text { Signaling Variables }\end{array}$} \\
\hline Distance from S.G. $(-)$ & $\begin{array}{c}-0.26^{* * *} \\
(5.82)\end{array}$ & $\begin{array}{l}-0.23^{* * *} \\
(5.49)\end{array}$ \\
\hline Outlier Signal (+) & $\begin{array}{l}0.20^{* * *} \\
(3.52)\end{array}$ & $\begin{array}{l}0.15^{* *} \\
(2.67)\end{array}$ \\
\hline \multicolumn{3}{|l|}{ Justice Specific Controls } \\
\hline Ideological propensity $(+)$ & $\begin{array}{l}0.68^{* * *} \\
(10.78)\end{array}$ & $\begin{array}{l}0.71^{* * *} \\
(11.05)\end{array}$ \\
\hline Freshman $(+)$ & - & $\begin{array}{r}0.14^{*} \\
(1.39)\end{array}$ \\
\hline \multicolumn{3}{|l|}{ Case Specific Controls } \\
\hline Legal salience (-) & $\begin{array}{l}- \\
-\end{array}$ & $\begin{array}{l}-0.30^{* * *} \\
(3.96)\end{array}$ \\
\hline Political salience $(-)$ & $\begin{array}{l}- \\
-\end{array}$ & $\begin{array}{l}-0.31^{* * *} \\
(4.98)\end{array}$ \\
\hline Invitation $(+)$ & - & $\begin{array}{c}-0.13 \\
(1.08)\end{array}$ \\
\hline Complexity $(+)$ & $\begin{array}{l}- \\
-\end{array}$ & $\begin{array}{c}-0.08 \\
(1.22)\end{array}$ \\
\hline Constant & $\begin{array}{c}0.55 \\
(9.31)\end{array}$ & $\begin{array}{c}0.63 \\
(3.66)\end{array}$ \\
\hline -2 Log Likelihood & -1915.3 & -1852.9 \\
\hline Pseudo $\mathrm{R}^{2}$ & 0.23 & 0.24 \\
\hline Correctly predicted $\%$ & $77.21 \%$ & $77.23 \%$ \\
\hline Reduction in error \% & $30.1 \%$ & $30.1 \%$ \\
\hline Number of Observations & 3888 & 3888 \\
\hline
\end{tabular}

Note: Entries are unstandardized coefficients from probit estimation ( $\mathrm{t}$-statistics are in parentheses and based on robust standard errors). Fixed effects for each S.G. are included in the model, but not reported.

${ }^{*} \mathrm{p}<0.10{ }^{* *} \mathrm{p}<0.01{ }^{* * *} \mathrm{p}<0.001$ (one-tailed).

significant. ${ }^{14}$ The variable that taps Distance from S.G. is negative and significant. This suggests that when the S.G. files a brief advocating the conservative position, justices who are further ideologically from the S.G. are less likely to vote in the conservative direction. Likewise, when the S.G. advocates a liberal outcome, ideologically distant justices are less likely to follow the S.G.'s cue. Most significantly, this relationship holds even after controlling for the ideology of the justice (Ideological Propensity), whose

\footnotetext{
${ }^{14}$ Although our dependent variable is limited to amicus filings by the Office of the S.G. (see footnote 1), we estimated the two models reported in table 2 using data that also includes cases where the U.S. was a party and appealed a lower court loss. These appeals were filed at the discretion of the S.G. Both key independent variables (ideological distance and outlier signal) are significant at 0.01 , onetailed levels or higher. These results are available upon request.
}

coefficient is also statistically significant. As Table 3 makes clear, even if one assumes that their Ideological Propensity is identical, a justice who has preferences almost identical to the S.G. is 1.5 times more likely to vote with the S.G. than a justice who is extremely distant from the S.G. Justices who are ideologically closer to a president tend to disproportionately vote with the S.G. The fact that this pattern holds even after controlling for each justice's ideology is consistent with our theoretical claim: a receiver is more likely to trust the credibility of a signal sent by one with similar interests.

The statistically significant Outlier variable indicates when the S.G. advocates a position that runs contrary to his usual ideological position; the cue is taken more seriously by ideologically distant justices. A justice is more likely to support a conservative S.G. when the S.G. advocates a liberal rather than a conservative outcome. As seen in Table 3, justices are likely to support the S.G. $68 \%$ of the time when the S.G. files a brief that is in the eyes of the justice consistent with the S.G.'s ideological orientation (Outlier equals 0 ). In contrast, when the S.G. files an amicus brief urging an outcome that the justice believes runs counter to the S.G.'s ideological orientation, he is supported $83 \%$ of the time. Under conditions where it is clear that the S.G. is not distorting information, justices are most likely to support the S.G.

Although we are primarily interested in testing the fit of a signaling model to account for variation in the S.G.'s success before the Court, several of our independent

\section{TABLE 3 Simulated Effects of Significant Independent Variables}

Distance from S.G.

Minimum Value (0.001) $\quad 0.78$

Maximum Value (3.42) 0.52

Outlier Signal

Minimum Value (0.00) $\quad 0.68$

Maximum Value (3.42) 0.83

Freshman

Minimum Value (0.00) $\quad 0.69$

Maximum Value (1.00) 0.74

Political Salience

Minimum Value (0.00) $\quad 0.73$

Maximum Value (1.00) 0.62

Legal Salience

Minimum Value (0.00) $\quad 0.71$

Maximum Value (1.00) $\quad 0.60$ 
control variables are statistically significant. As we expected, the S.G.'s influence is diminished for both politically and legally salient cases. Thus, on cases where the views of the justices are most likely to be fixed, the value of the information provided by the S.G. is diminished.

Our freshman variable is statistically significant at the 0.10 level. This may occur because new justices are more dependent on the information provided by external sources and may be acting out of gratitude for their nomination. Our Ideological Propensity variable suggests that conservative justices are more likely to support the S.G. when he advocates a conservative outcome and liberal justices are less likely to support the S.G. Although Segal (1988) and Segal and Spaeth (1993) have demonstrated this, including each justice's ideology as a control in our model increases our confidence in the apparent impact of the variables that tap political signals from the S.G. The coefficient on the complexity variable is insignificant. Finally, contrary to expectations, the S.G. does not have more influence when he was invited to participate.

\section{Who Wins?}

It s clear that the Office of the S.G. disproportionately wins before the Supreme Court. However, the success of administrations before the Court varies over time. Solicitors general during the Carter and Clinton administrations prevailed in less than $70 \%$ of the cases in which the S.G. participated as an amicus on civil liberties cases. During the Eisenhower, Kennedy, and Johnson administrations, the solicitors general prevailed over $85 \%$ of the time they participated as an amicus. More recently, during the administration of George W. Bush, the Court has endorsed the position advocated by the S.G. in $96 \%$ of the civil liberties cases in which the S.G participated as a friend of the Court. Because a majority of the bench determines the disposition of a case (e.g., the Court's decision to affirm or reverse), the justice located in the middle of the bench is uniquely empowered to determine whether the Court's ruling will be consistent with the S.G.'s amicus brief. Our signaling model suggests that Court support for the S.G.'s position will depend on the tendency of an administration to embrace "outlier" positions and the ideological proximity between the Court median and the Solicitor.

To test this conjecture, in Table 4 we model whether the Court's ruling is consistent with the position advocated by the S.G. in the 485 civil liberties case where the S.G. participated as an amicus. Our dependent variable takes the value of 1 if the S.G.'s position prevailed, 0 otherwise. As independent variables, we include two variables that tap how the median justice for each case perceives
TABle 4 Probability of the Court Ruling in a Manner Consistent with the Outcome Advocated by the S.G. in an Amicus Brief

\begin{tabular}{lcc}
\hline $\begin{array}{l}\text { Variable (expected sign) } \\
\text { Signaling Variables }\end{array}$ & & \\
\hline Median Distance (-) & $-0.50^{* * *}$ & $-0.56^{* * *}$ \\
& $(3.31)$ & $(3.65)$ \\
Median Outlier (+) & $0.24^{* *}$ & $0.20^{*}$ \\
& $(1.85)$ & $(1.53)$ \\
Case Specific Controls & & \\
Legal salience (-) & - & $-0.31^{*}$ \\
& - & $(1.61)$ \\
Political salience (-) & - & $-0.25^{* *}$ \\
& - & $(1.75)$ \\
Invitation $(+)$ & - & -0.22 \\
& - & $(1.04)$ \\
Complexity (+) & - & -0.03 \\
& - & $(0.18)$ \\
Constant & $1.05^{* * *}$ & $1.26^{* * *}$ \\
& $(7.50)$ & $(7.82)$ \\
-2 Log Likelihood & -266.8 & -262.5 \\
Pseudo $\mathrm{R}^{2}$ & 0.02 & 0.04 \\
Number of Observations & 485 & 485 \\
\hline
\end{tabular}

Note: Entries are unstandardized coefficients with t-statistics in brackets.

${ }^{*} \mathrm{p}<0.10 ;{ }^{* *} \mathrm{p}<0.01{ }^{* * *} \mathrm{p}<0.001$ (one-tailed).

the S.G.'s signal. The Median Distance variable is the ideological distance between the median justice and the S.G. We used the same bridge observations discussed earlier to construct our ideological scores. Likewise, the Median Outlier variable is the distance between the median justice and the S.G. whenever the S.G. is more conservative than the median justice and advocates a liberal position (and vice versa). In all other instances, this variable is a 0 . In addition to these two independent variables, we include in the right hand column of Table 4 the same case-specific controls from the right hand column of Table 2 .

Our results suggest that the signaling model helps account for variation in S.G.s' success rates when participating as amici. Both of our variables that explain how the median justice is likely to view the signal sent by the S.G. are statistically significant. Whereas the Median Distance variable is significant at the 0.001 level, the Median Outlier variable is significant at the 0.07 level. The control variables that tap whether a case is politically and/or legally salient are in the negative direction and statistically significant. Once again, this suggests that the capacity of the S.G. to influence the outcome of a case is diminished in cases that are salient. 


\section{Conclusion}

Previous analyses of the effect of the solicitor general on the Court offer nonideological, institutional explanations. Such accounts suggest that the S.G. tends to win because he is perceived to be advocating legal principles important to the bench or because of his skill and experience. These accounts place little weight on the policy preferences of the players suggesting instead that the positions of the solicitor general evenly affect the decisions of the justices across the bench and over time. By developing a theory that takes into account the preferences of the S.G. and the individual justices, we are able to develop a more nuanced explanation for the role played by the S.G.

To be sure, our results suggest that the involvement of the solicitor general has a direct impact on the decisions reached by the Court. The participation of the solicitor general appears to influence the actions of all justices and thus to shape Court outcomes. This finding comports with McGuire (1998) and others who show the unique status afforded the solicitor general by the members of the Supreme Court bench. Most likely, the ability of the S.G. to affect justices' choices helps to account for part of the success rates of solicitor generals over the postwar period when they file amicus briefs before the Court. Although our results do not contradict the view that the S.G. is disproportionately successful before the bench, this success is in part a reflection of a political process that is outside the purview of traditional explanations for the success of the S.G. Our empirical results suggest that amicus briefs filed by the solicitor general are perceived as ideological signals by the justices. All justices may be receptive to cues sent from the solicitor general, but justices are especially receptive to such cues under two conditions-when they are ideologically close to the president and S.G. or when the S.G. files an amicus brief that contradicts his ideological predisposition. These findings are based upon cases where the S.G.'s decision to participate was for the most part discretionary. It is possible that the S.G.'s briefs are interpreted differently when his participation is not discretionary.

Viewing the solicitor general solely as an apolitical legal expert is inconsistent with our results. The solicitor general's influence should be seen in political terms. He is more likely to persuade his ideological allies, and all justices are less likely to be suspicious of him when he takes positions that seem to be against his ideological predispositions. The "tenth justice" is no less political than the other nine.

Those who are active in the Supreme Court bar routinely attempt to influence Court outcomes. With a few notable exceptions, such attempts are rarely incorporated into our models of judicial decision making. Instead, political scientists tend to assume that justices are motivated by preferences that are independent of the filings and arguments of those who appear before the Court. Our work demonstrates that when it comes to his participation as an amicus, the S.G. can influence justices by signaling to them information about how a case should be decided. However, like all actors who send signals, the effectiveness of the signal varies in a predictable fashion. Although our work is limited in scope to the signals sent by the S.G. when he participates as an amicus on civil liberties, it is important to note that other actors (such as interest groups, state governments, and others) also routinely try to signal the Court on a variety of cases. Although such actors lack the institutional status of the S.G., we suspect that their influence with the justices varies predictably as well.

\section{Appendix Additional Details on Interinstitutionally Comparable Preference Estimates}

Our model requires us to place presidents and Supreme Court justices on a common ideological scale. Although McCarty and Poole's common space scores (1995) provide a measure that can be used to compare the House, Senate, and the president, a measure that extends to cover the Supreme Court did not exist before Bailey and Chang (2001). Previous efforts to compare preferences between the Court and other branches assumed that comparability of percent liberal scores across institutions, something that Bailey and Chang (2001) and Bailey (2003) demonstrate is unlikely to be justified.

The bridge observations we utilize are observations of actors from one institution taking positions on votes in another institution (Bailey 2003). For example, statements such as the following place presidential preferences in the Court context: President George H.W. Bush stated on June 24, 1992, "I am very disappointed by the Supreme Court's decision in Lee v. Weisman" (Bush Library Database). Statements such as the following place U.S. Senators in the judicial context: in 1956, 21 Southern Democrats placed in the Congressional Record (102, 4459-60) the "Southern Manifesto" declaring Brown v. Board of Education "a clear abuse of power." To ensure the comparability between the bridges that exist across three branches of government, observations are limited to statements, votes, and cases that pertain to civil liberties or civil rights (broadly construed). 
Because we are interested in analyzing the voting behavior of justices on cases where the executive branch filed an amicus brief, our preference estimates are based on a dataset that excludes cases where the S.G. filed an amicus brief. ${ }^{15}$ Inclusion of these cases could potentially create a situation in which the ideology measure actually incorporates the effect of the S.G. on justice preferences. Our strategy follows Snyder and Groseclose (2000), who tested for party influence on congressional voting. They excluded votes where party influence was likely in their preference estimation step and then used these preferences as a control variable in their analysis of votes for which party influence was deemed more likely.

The measurement model at the heart of the estimation procedure is the following standard latent variable random utility model derived from a spatial utility maximization model:

$$
\operatorname{Pr}\left(\mathrm{y}_{\mathrm{it}}=1\right)=\Phi\left(\mathrm{a}_{\mathrm{t}}\left(\mathrm{X}_{\mathrm{it}}-\mathrm{k}_{\mathrm{t}}\right)\right)
$$

where $y_{i t}$ is the vote of individual $i$ on vote $t$ (where conservative votes are coded 1), $a_{t}$ is the "discrimination" parameter that determines the extent to which the vote discriminates among ideological types, $\mathrm{X}_{\mathrm{it}}$ is the ideological position of individual $\mathrm{i}$ at vote $\mathrm{t}, \mathrm{k}_{\mathrm{t}}$ is the vote "cutpoint" that determines how the vote divides liberals and conservatives, and $\Phi$ is the normal cumulative distribution function. Notice that for an individual with an ideal point at the cutpoint, the probability of voting conservatively is $50 \%$. A high discrimination parameter indicates that the vote distinguishes well between individuals with ideal points above and below the cutpoint; a low discrimination parameter indicates there is considerable "nonideological" voting.

In order to allow for a justice's ideological positions to vary over time (as many suspect occurred for Black, Blackmun, Souter, and others), justice ideal points are allowed to vary over time according to a quadratic function of years of service. The functional form is flexible enough to reasonably match the patterns of ideological change found in Martin and Quinn (2002) and Epstein, Hoekstra, Segal, and Spaeth (1998). The estimation uses a Gibbs sampler algorithm that samples repeatedly from the conditional distributions of each variable. Given enough iterations, sampled values will be from the underlying true joint distribution (see, e.g., Albert and Chibb 1993). Clinton, Jackman, and Rivers (2001) present a comprehensive discussion of MCMC application to ideal point estimation.

\footnotetext{
${ }^{15}$ In a previous version of this article, we included these cases when estimating preferences; the results were similar to those reported below.
}

\section{References}

Albert, James, and Siddhartha Chib. 1993. Bayesian Analysis of Binary and Polychotomous Response Data. Journal of the American Statistical Association 88(June):669-79.

Bailey, Michael. 2003. Bridging Institutions: Bayesian Common Space Preference Estimates for Presidents, Senators, and Justices, 1946-2002. Unpublished manuscript, Georgetown University.

Bailey, Michael, and Kelly H. Chang. 2001. "Comparing Presidents, Senators, and Justices: Interinstitutional Preference Estimation." Journal of Law, Economics \& Organization 17(2):477-508.

Brenner, Saul. 1998. "Measuring the Importance of Supreme Court Decisions." Law Library Journal 90(Summer):18392.

Brenner, Saul, and Timothy M. Hagle. 1996. "Opinion Writing and Acclimation Effect." Political Behavior 18(3):235-61.

Caldeira, Gregory A., and John R. Wright. 1988. "Organized Interests and Agenda Setting in the U.S. Supreme Court." American Political Science Review 82(December):110927.

Calvert, Randall. 1985. "The Value of Biased Information: A Rational Choice Model of Political Advice.” Journal of Politics 47(June):530-55.

Caplan, Lincoln. 1987. The Tenth Justice: The Solicitor General and the Rule of Law. New York: Vintage Books.

Clinton, Josh, Simon Jackman, and Doug Rivers. 2001. The Statistical Analysis of Legislative Roll Call Data. Unpublished manuscript, Stanford University.

Cooper, James. 1990. "Note, The Solicitor General and the Evolution of Activism." Indiana Law Journal 65(Summer):67595.

Cook, Beverly B. 1993. "Measuring the Significance of U.S. Supreme Court Decisions." Journal of Politics 55(November):1127-39.

Crawford, Vincent, and Joel Sobel. 1982. Strategic Information Transmission. Econometrica 50(6):1431-51.

Days, Drew. 1994. "In Search of the Solicitor General's Clients: A Drama with Many Characters." Kentucky Law Journal 83(2):485-507.

Epstein, Lee, and Jack Knight. 1998. The Choices Justices Make. Washington: Congressional Quarterly Press.

Epstein, Lee, and Jeffrey A. Segal. 2000. "Measuring Issue Salience." American Journal of Political Science 44(January):66-83.

Epstein, Lee, Valerie Hoekstra, Jeffrey Segal, and Harold Spaeth. 1998. "Do Political Preferences Change? A Longitudinal Study of U.S. Supreme Court Justices." Journal of Politics 60 (August):801-18.

Epstein, Lee, Jeffrey A. Segal, Howard Spaeth, and Thomas Walker. 1996. The Supreme Court Compendium, $2^{\text {nd }}$ ed. Washington: Congressional Quarterly Press.

Epstein, Lee, Jeffrey A. Segal, Howard Spaeth, and Thomas Walker. 2003. The Supreme Court Compendium, $3^{\text {rd }}$ ed. Washington: Congressional Quarterly Press.

Eskridge, Willian N. Jr., and Philip P. Frickey. 1994. "The Supreme Court 1993 Term: Foreword: Law as Equilibrium.” Harvard Law Review 108(November):26-108. 
Fraley, George III. 1996. "Note, Is the Fox Watching the Henhouse? The Administration's Control of FEC Litigation through the Solicitor General." Administrative Law Review 9(Winter): 1215 .

Galanter, Marc. 1974. "Why the 'Haves' Come Out Ahead: Speculation on the Limits of Legal Change." Law and Society Review 9(Fall):95-160.

Gibson, James. 1997. United States Supreme Court Judicial Database, Phase II 1953-1993. First ICPSR version. ICPSR Number 6987.

Greenhouse, Linda. 2003. "Bush and Affirmative Action: News Analysis; Muted Call in Race Case.” New York Times, section A, pg. 1, January 17.

Groseclose, Tim, Steven D. Levitt, and James M. Snyder, Jr. 1999. "Comparing Interest Group Scores across Time and Chambers: Adjusted ADA Scores for the U.S. Congress.” American Political Science Review 93(1):33-50.

Hagle, Timothy M. 1993. "'Freshman Effects' for Supreme Court Justices." American Journal of Political Science 37(4):1142-57.

Johnson, Timothy R. 2002. "The Supreme Court, the Solicitor General, and the Separation of Powers." Unpublished manuscript, University of Minnesota.

Lee, Rex E. 1986. "Lawyering for the Government: Politics, Polemics \& Principle." Ohio State Law Journal 47(Summer):595-601.

Li, Hao, and Suen Wing. 2004. Delegating Decisions to Experts. Journal of Political Economy 112(S1):S311-35.

Maltzman, Forrest, James F. Spriggs II, and Paul J. Wahlbeck. 2000. Crafting Law on the Supreme Court: The Collegial Game. Cambridge and New York: Cambridge University Press.

Martin, Andrew, and Kevin Quinn. 2002. Dynamic Ideal Point Estimation via Markov Chain Monte Carlo for the U.S. Supreme Court, 1953-1999. Political Analysis 10(2):13453.

McCarty, Nolan, and Keith Poole. 1995. "Veto Power and Legislation: An Empirical Analysis of Executive and Legislative Bargaining from 1961 to 1986." Journal of Law, Economics and Organization 11(2):282-312.

McGuire, Kevin T. 1998. "Explaining Executive Success in the U.S. Supreme Court." Political Research Quarterly 51(June):505-26.

Meinhold, Stephen S., and Steven A. Shull. 1998. "Policy Congruence Between the President and the Solicitor General." Political Research Quarterly 51(June):527-37.

Murphy, Walter F. 1964. Elements of Judicial Strategy. Chicago: University of Chicago Press.

O'Connor, Karen. 1983. "The Amicus Curiae Role of the U.S. Solicitor General in Supreme Court Litigation." Judicature 66(December-January):256-64.

Pacelle, Richard L. Jr. 2002. The Role of the Supreme Court in American Politics: The Least Dangerous Branch? Boulder: Westview Press.

Pacelle, Richard L. Jr. 2003. Between Law and Politics: The Solicitor General and the Structuring of Race, Gender, and Reproductive Rights Litigation. College Station: Texas A\&M University Press.
Perry, H.W. Jr. 1991. Deciding to Decide: Agenda Setting in the United States Supreme Court. Cambridge: Harvard University Press.

Provine, Doris Marie. 1980. Case Selection in the United States Supreme Court. Chicago: University of Chicago Press.

Puro, Steven. 1981. "The United States as Amicus Curiae." In Courts, Law and Judicial Processes," ed. S. Sideny Ulmer. New York: The Free Press, pp. 220-29.

Salokar, Rebecca M. 1992. The Solicitor General: The Politics of Law. Philadelphia: Temple University.

Scigliano, Robert. 1971. The Supreme Court and the Presidency. New York: Free Press.

Segal, Jeffrey A. 1988. "Amicus Curiae Briefs by the Solicitor General during the Warren and Burger Courts: A Research Note." Western Political Quarterly 41(March):13544.

Segal, Jeffrey A., and Cheryl D. Reedy. 1988. "The Supreme Court and Sex Discrimination: The Role of the Solicitor General." Western Political Quarterly 41(September):55368.

Segal, Jeffrey A., and Howard J. Spaeth. 1993. The Supreme Court and the Attitudinal Model. New York: Cambridge University Press.

Segal, Jeffrey A., and Howard J. Spaeth. 2002. The Supreme Court and the Attitudinal Model Revisited. New York: Cambridge University Press.

Shipan, Charles R., and William R. Lowry. 2001. "Environmental Policy and Party Divergence in Congress." Political Research Quarterly 54(June):245-64.

Snyder, James M. Jr., and Tim Groseclose. 2000. "Estimating Party Influence in Congressional Roll-Call Voting." American Journal of Political Science 44(April):193-211.

Spaeth, Harold. 1999. Expanded United States Supreme Court Judicial Database, 1946-1968 Terms [Computer file]. 4th ICPSR version. East Lansing: Michigan State University, Dept. of Political Science [producer], 1998. Ann Arbor: Inter-university Consortium for Political and Social Research [distributor].

Spaeth, Harold. 2002. United States Supreme Court Judicial Database, 1953-2000 Terms. From http://www.ssc.msu.edu/ $\sim$ pls/pljp/, updated: May 15, 2002.

Spriggs, James F., and Paul J. Wahlbeck. 1997. “Amicus Curiae and the Role of Information at the Supreme Court." Political Science Quarterly 50(June):365-86.

Starr, Kenneth. 2002. First Among Equal: The Supreme Court in American Life. New York: Warner Books.

Tanenhaus, Joseph, Marvin Schick, Matthew Muraskin, and Daniel Rosen, "The Supreme Court's Certiorari Jurisdiction: Cue Theory.” In Judicial Decision-Making, ed. Glendon Schubert. 1963. New York: Free Press, pp. 111-32.

Ulmer, S. Sidney. 1984. “The Supreme Court's Certiorari Decisions: Conflict as a Predictive Variable." American Political Science Review 78(December):901-11.

Ulmer, S. Sidney, and David Willison. 1985. "The Solicitor General of the United States as Amicus Curiae in the U.S. Supreme Court, 1969-1983 Terms.” Delivered at the annual meeting of the American Political Science Association. 